\title{
Interactive comment on "SHORT COMMUNICATION: Massive Erosion in Monsoonal Central India Linked to Late Holocene Landcover Degradation” by Liviu Giosan et al.
}

\section{Liviu Giosan et al.}

Igiosan@whoi.edu

Received and published: 27 September 2017

This comment by Y. Kulkarni is a duplication. We respond to the final of his two comments, which are mostly identical, which we consider as his final version.

Interactive comment on Earth Surf. Dynam. Discuss., https://doi.org/10.5194/esurf-2017-35, 2017. 